\title{
PENGEMBANGAN MODEL KURSUS WIRAUSAHA DESA PEMBIBITAN KARET UNGGUL UNTUK MENINGKATKAN KOMPETENSI BERWIRAUSAHA WARGA BELAJAR
}

\author{
Badawi* \\ Sutaryat Trisnamansyah**
}

\begin{abstract}
This research is grounded on the fact that a lot of civillians are unemployed as they do not have enough knowledge and skills to work. On the other side, the increasing number of conversions from horticulture plants to rubber plants has caused the people's demand for top rubber seeds to increase too. This research therefore wanted to find out the type of KWD Model to increase the entrepreneurship competency of the learning participants. Based on this objective, this research developed correlational and differential research questions. The correlational investigation was needed to examine the contribution of the independent variables toward the dependent variable (the increase of the entrepreneurship competency) of the learning participants. Meanwhile the differential investigation was needed to examine the effectiveness of the model. The result of the research indicates there is a positive and significant contribution of the learning participant's interest, achievement motivation, the learning participant's participation, technical resourceperson's competence, the training curriculum, the infrastructure and facilities, the intstructional process, and the executing institution toward the increase of the entrepreneurship competency of of the learning participants both individually or all together. The test of model effectiveness proves a positive and significant difference between the designed model and the existing model.
\end{abstract}

Keywords: KWD (Village Entrepreneurship Course), entrepreneurship competence, human resources, model effectiveness

\begin{abstract}
Abstrak
Penelitian ini dilatarbelakangi oleh banyaknya warga masyarakat yang menganggur karena tidak mempunyai pengetahuan dan keterampilan. Sementara itu, banyak konversi lahan dari tanaman hortikultura ke tanaman perkebunan karet, sehingga banyak permintaan bibit karet unggul untuk memenuhi kebutuhan masyarakat. Penelitian ini bertujuan menemukan Model Kursus Wirausaha Desa yang dapat meningkatkan kompetensi berwirausaha warga belajar. Berdasarkan permasalahan utama tersebut, dikembangkan pertanyaan penelitian korelasional dan perbedaan. Peneiltian korelasional untuk menguji kontribusi variabel-variabel bebas terhadap varibel terikat (peningkatan komptensi berwirausaha) warga belajar. Sedangkan penelitian perbedaan untuk menguji efektivitas model. Hasil uji hipotesis penelitian korelasional terdapat kontribusi yang positif dan signifikan minat warga belajar, motivasi berprestasi, partisipasi warga belajar, kompetensi narasumber teknis, kurikulum pelatihan, sarana dan prasarana, proses pembelajaran, dan lembaga penyelenggara terhadap peningkatan kompetensi berwirausaha baik secara sendiri atau bersama-sama. Kemudian dari hasil uji efektivitas model terbukti terdapat perbedaan yang positif dan signifikan antara model yang dirancang dan model yang sudah ada.
\end{abstract}

Kata-kata kunci: KWD, kompetensi berwirausaha, sumber daya manusia, efektivitas model

\section{PENDAHULUAN}

Pada awal tahun 1998, badai krisis melanda Indonesia, krisis multidimensional yang berkepanjangan, nyaris menggerogoti tatanan kehidupan bermasya-

* Dosen Sekolah Tinggi Keguruan dan IImu Pendidikan (STKIP) Muhammadiyah Kotabumi Lampung

** Guru Besar Jurusan Pendidikan Luar Sekolah SPS UPI rakat, berbangsa, dan bernegara. Keadaan tersebut berpengaruh terhadap stabilitas perekonomian Indonesia hingga titik nadir, stabilitas politik terguncang yang menyebabkan kemiskinan dan daya beli masyarakat rendah. Instabilitas ekonomi dan politik tersebut berdampak 
luas di antaranya daya beli masyarakat rendah dan miskin, menurunnya kualitas pendidikan yang berdampak menurunnya kualitas sumber daya manusia (SDM). Kondisi tersebut disebabkan oleh adanya arus global yang melanda negara-negara di dunia termasuk Indonesia. Oleh karena itu, untuk dapat menanggulangi berbagai permasalahan di Indonesia diperlukan SDM yang tangguh agar mampu membendung pengaruh negatif akibat globalisasi dan bekerja keras dengan semboyan "Think Globally and Act Locally", yaitu berpikir global dan bertindak lokal untuk menggapai kemajuan bangsa dan mengubah kelemahan menjadi kekuatan.

SDM yang berkualitas akan mampu berpikir kritis dan analitis terhadap berbagai fenomena yang muncul, sehingga berbagai permasalahan yang timbul akan dapat diminimalisir dan dicarikan jalan keluarnya dengan baik. Suryadi (2009: 33) mengemukakan bahwa pembangunan pendidikan negara Indonesia, khususnya pembangunan pendidikian nonformal mengalami kemajuan yang berarti Human Development Index (HDI).

Lebih lanjut, Suryadi (2010) mengemukakan bahwa permasalahan pendidikan terkait dengan SDM Indonesia dapat dilihat dari turun naiknya peringkat HDI Indonesia. Sejak tahun 1995, peringkat HDI Indonesia menurun dari peringkat ke-104 pada tahun 1995, ke109 pada tahun 2000 , ke-110 pada tahun 2002 , ke-112 pada tahun 2003, dan kemudian sedikit membaik ke111 dari 172 negara pada tahun 2004, serta ke-110 pada tahun 2005. Memasuki tahun2006, posisi Indonesia mulai naik hingga berada di posisi 108 , dan pada tahun 2007 menjadi urutan ke-107. Kenaikan tersebut dipicu oleh peningkatan angka keniraksaraan penduduk Indoesia yang merupakan salah satu indikator kunci penilaian.

Upaya pemberantasan buta aksara yang dituangkan dalam Keputusan Presiden No 5 tahun 2006 tentang Gerakan Nasional Pemberantasan Buta Aksara sangat efektif untuk meningkatkan peringkat HDI. Selain itu, reformasi pendidikan seharusnya mengacu pada pembangunan sosial dan ekonomi serta berbasis kebutuhan tenaga kerja di tingkat lokal dan nasional.

Peningkatan kualitas SDM berkaitan erat dengan peningkatan HDI. Oleh karena itu, upaya meningkatkan HDI merupakan suatu keniscayaan untuk mendongkrak kualitas SDM agar bangsa Indonesia dapat sejajar dengan bangsa-bangsa lain. Salah satu upaya yang dapat ditempuh untuk meningkatkan kualitas SDM adalah melalui pendidikan karena di dalam pendidikan terjadi pembelajaran yaitu proses belajar yang dilakukan oleh murid dan mengajar dilakukan oleh guru. Hakikat dari belajar adalah perubahan, melalui kegiatan pembelajaran akan menghasilkan perubahan yaitu peningkatan pengetahuan, keterampilan, dan sikap mental ke arah yang lebih baik. Itu semua akan dapat tercapai jika pendidikan dirancang sesuai dengan tuntutan dan kebutuhan zaman.

Buchori dalam Safaruddin (2008: 2) menjelaskan bahwa hal yang krusial dilakukan di tengah perubahan zaman yang imperatif adalah mendesain relevansi pendidikan nasional supaya lebih dinamis, responsif, dan antisipatif. Pembangunan masyarakat dapat dilakukan melalui jalur pendidikan baik formal, informal, maupun nonformal. Direktorat Pembinaan Kursus dan Kelembagaan Dirjen PNFI (2008: 1-2), data strategis BPS bulan Agustus 2008 menunjukkan jumlah angkatan kerja Indonesia sebanyak 111,4 juta orang. Dari jumlah tersebut, tercatat 9,42 juta $(8,48 \%)$ orang, merupakan penganggur terbuka terdiri dari 7,4 juta orang $(78,38 \%)$ adalah pemuda usia produktif, yang berdomisili di pedesaan 4.186 .703 orang $(44,4 \%)$ dan di perkotaan 5.240 .887 orang $(55,6 \%)$.

Selanjutnya penduduk miskin Indonesia saat ini mencapai 34,96 juta orang $(15,42 \%)$ dengan komposisi 22.189.122 orang (63\%) berada di desa dan 12.770 .888 orang $(37 \%)$ di kota. Bagi generasi muda yang ingin memiliki keterampilan khusus untuk memasuki dunia kerja, lembaga kursus, dan pelatihan merupakan pilihan utama. Apalagi bagi 8,96 juta penganggur dari total angkatan kerja sebanyak 113,83 juta berdasarkan data BPS (2009), lembaga kursus, dan pelatihan tentu sangat bermanfaat.

Sudjana (2000: 142) mengemukakan bahwa tujuan dari pelaksanaan program PLS adalah agar warga belajar dapat tumbuh dan berkembang sedini mungkin dan sepanjang hidupnya, memiliki pengetahuan, keterampilan, dan sikap mental yang diperlukan untuk mengembangkan diri, serta bekerja mencari nafkah. Dengan demikian, PLS mencarikan solusi untuk memecahkan masalah tanpa masalah. Kursus Wirausaha Desa (KWD) diharapkan meningkatkan pengetahuan dan keterampilan warga belajar, sehingga warga masyarakat mampu melakukan usaha dalam bidang pembibitan karet sesuai dengan anjuran dinas perkebunan. Bibit karet unggul yang dihasilkan dapat digunakan untuk kebutuhan sendiri maupun masyarakat lain yang membutuhkan. Selain dapat melakukan usaha pembibitan, dapat juga memberikan jasa atau layanan tenaga kerja dalam pembibitan karet unggul.

Di Desa Semuli Jaya Kecamatan Abung Semuli dan Desa Bumi Raharja Kecamatan Abung Surakarta sebagian petani perkebunan miskin. Permasalahan utama bagi petani adalah rendahnya tingkat pendidi- 
kan masyarakat, tidak memiliki pengetahuan, keterampilan dan pekerjaan tetap, sehingga petani hidup miskin. Banyak petani yang beralih dari petani hortikultura ke perkebunan karet tetapi sebagian petani memilih menanam bibit karet alam, karena tidak tersedia bibit karet unggul yang harganya murah dan struktur pasar yang tidak berpihak kepada petani, serta hasil perkebunan harus dijual kepada pemilik modal dengan harga yang lebih rendah dari harga pasar.

Perumusan masalah penelitian ini adalah "Model kursus wirausaha desa bagaimana yang dapat meningkatkan kompetensi berwirausaha warga belajar di Desa Semuli Jaya Kecamatan Abung Semuli dan Desa Bumi Raharja Kecamatan Abung Surakarta Kabupaten Lampung Utara?"

Berdasarkan permasalahan utama di atas, dijabarkan ke dalam beberapa pertanyaan penelitian sebagai berikut.

1. Bagaimana model konseptual kursus wirausaha desa dalam upaya meningkatkan kompetensi berwirausaha warga belajar?

2. Bagaimana implementasi model kursus wirausaha desa dalam upaya meningkatkan kompetensi ber- wirausaha warga belajar?

3. Bagaimana efektivitas model kursus wirausaha desa dalam upaya meningkatkan kompetensi berwirausaha warga belajar?

Tujuan umum penelitian ini adalah menghasilkan model KWD pembibitan karet unggul untuk meningkatkan kompetensi berwirausaha warga belajar di Desa Semuli Jaya Kecamatan Abung Semuli dan di Desa Bumi Raharja Kecamatan Abung Surakarta Kabupaten Lampung Utara. Sedangkan tujuan khusus adalah untuk mengetahui.

1. Penyelenggaraan kursus/ pelatihan Pendidikan Kecakapan Hidup (PKH) di kabupaten Lampung Utara dan informasi mengenai kontribusi komponen-komponen pelatihan dengan peningkatan kompetensi berwirausaha warga belajar setelah mengikuti pelatihan.

2. Model konseptual KWD untuk meningkatkan kompetensi berwirausaha warga belajar.

3. Implementasi model KWD untuk meningkatkan kompetensi berwirausaha warga belajar.

4. Efektivitas model KWD untuk meningkatkan kompetensi berwirausaha warga belajar.

\section{KAJIAN TEORETIS}

Pengembangan Sumber Daya Manusia (PSDM) diterjemahkan dari bahasa Inggris Human Resources Development (HRD). Istilah ini dibangun dari dua konsep, yaitu Pengembangan dan Sumber Daya Manusia. Secara umum, pengembangan adalah suatu proses aktif untuk mengubah suatu keadaan ke keadaan lain yang lebih baik. Nadler dan Wiggs (1986) (dalam Depdagri dan LAN, 2007:4) mengatakan "aktivitas pengembangan tidak berkaitan dengan pekerjaan tetapi berorientasi pada pertumbuhan, baik personel, maupun organisasi" (Development activities are not job related, but are oriented both personel and organizational growth). Tentu saja hal ini bukan berarti "pengembangan" tidak bermanfaat bagi kelancaran pengerjaan suatu pekerjaan.

If (2008: 209), sebuah prinsip dalam pengembangan masyarakat adalah bahwa kearifan datang dari 'bawah' ketimbang dari 'atas'. Hal ini ditekankan dalam karya Freire dan dalam pendekatan-pendekatan lain yang dibantu untuk menyuarakan kebutuhan masyarakat sendiri dan mengembangkan strategi sendiri dalam rangka memenuhi kebutuhan-kebutuhan tersebut (Kaufman \& Alfonso, 1997; Stiefel \& Wolfe, 1994; Holland \& Blackburn, 1998; Fals Borda \& Rahman,
1993).

Pengembangan SDM dapat ditempuh melalui pendidikan baik formal, nonformal, dan informal. Melalui jalur pendidikan nonformal dapat berbentuk kursus atau pelatihan untuk meningkatkan kualitas SDM sehingga dapat meningkatkan kualitas hidupnya dan kesejahteraan hidupnya. Undang-Undang RI No.20 Tahun 2003 Pasal 26 menyatakan (1) pendidikan nonformal diselenggarakan bagi masyarakat yang memerlukan layanan pendidikan yang berfungsi sebagai pengganti, penambah, dan/atau pelengkap pendidikan formal dalam rangka mendukung pendidikan sepanjang hayat.

Keberpihakan kepada masyarakat di lapisan bawah adalah suatu keharusan dan kewajaran bagi PNF. Strategi PNF bagi masyarakat lapisan bawah ini adalah "pengembangan SDM" (human resources development) melalui pembelajaran untuk membangun budaya berorganisasi di masyarakat (community organization), dan pengembangan ekonomi masyarakat (economic development) bagi pembangunan masyarakat (community development) serta sebagian penting dari kebijakan dan program-program pembangunan masyarakat dapat dilihat dalam gambar berikut. 


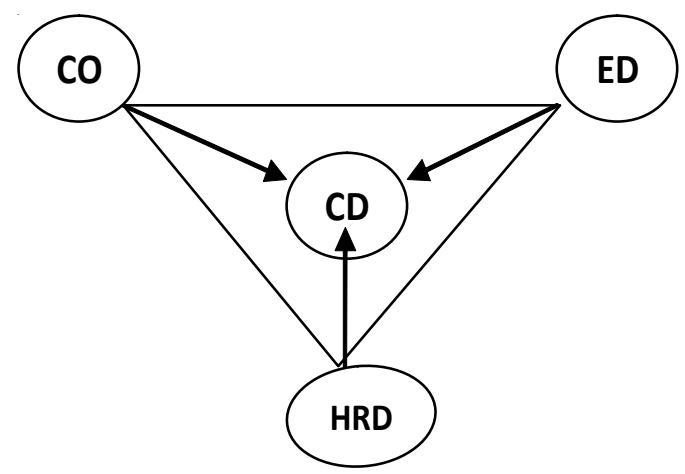

Gambar 1. Formulasi Kesenyawaan antara PNF dengan Pembangunan Masyarakat

Keterangan :

$\begin{aligned} \mathrm{CD}= & \text { Community Development (Pembangunan } \\ & \text { Masyarakat) } \\ \mathrm{HRD}= & \text { Human Resources Development } \\ & \text { (Pengembangan SDM) sebagai wujud } \\ & \text { program PNF } \\ \mathrm{CO}= & \text { Community Organization (Pengorganisasian } \\ & \text { Masyarakat) } \\ \mathrm{ED}= & \text { Economic Development (Pengembangan } \\ & \text { Ekonomi) }\end{aligned}$

Dengan demikian, pembangunan masyarakat/ Community Development (CD) merupakan upaya pengembangan SDM supaya masyarakat berorganisasi/ Community Organization (CO) dengan baik di masyarakat dan mampu meningkatkan taraf ekonomi masyarakat/ Economic Development (ED). Fungsi PNF adalah membelajarkan SDM di masyarakat sehingga mampu berorganisasi untuk meningkatkan taraf kehidupan di bidang ekonomi sebagai prasyarat untuk peningkatan aspek-aspek kehidupan lainnya.

Kursus Wirausaha Desa disingkat dengan KWD adalah program kursus yang diselenggarakan secara khusus di daerah pedesaan, untuk memberikan kesempatan bagi masyarakat desa agar memperoleh pengetahuan, keterampilan, dan menumbuhkembangkan sikap mental kreatif, inovatif bertanggung jawab serta berani menanggung resiko (sikap mental profesional) dalam mengelola potensi diri dan lingkungannya yang dapat dijadikan bekal untuk meningkatkan kualitas hidupnya (Depdiknas, 2007: 2).

KWD merupakan program Pendidikan Kecakapan Hidup (PKH) yang diselenggarakan oleh lembaga yang bergerak di bidang pendidikan nonformal dan informal untuk memberikan kesempatan belajar bagi masyarakat yang belum mendapat kesempatan untuk memperoleh pengetahuan, keterampilan menumbuhkembangkan sikap mental berwirausaha dalam mengelola potensi diri dan lingkungannya yang dapat dijadikan bekal untuk berusaha atau bekerja.

Adapun yang dimaksud dengan desa dalam program kursus wirausaha desa adalah jenis kecakapan yang berspektrum pedesaan bukan wilayah pedesaan, sasaranya adalah warga masyarakat yang tidak mempunyai pekerjaan (menganggur), usia produktif, yang mampu membaca menulis dan berhitung, serta tergolong keluarga yang tidak mampu. Setiap individu mengalami proses belajar karena terjadi perubahan pada dirinya dari waktu ke waktu, perubahan yang terjadi baik sengaja atau pun tidak sengaja merupakan hasil dari proses belajar. Menurut Gagne (1984); Syaiful Sagala (2005) (dalam Kamil, 2010: 36) bahwa belajar adalah suatu proses di mana organisme berubah perilakunya sebagai akibat dari pengalaman. Sedangkan Garet berpendapat bahwa belajar merupakan proses yang berlangsung dalam waktu lama melalui latihan maupun pengalaman yang membawa kepada perubahan diri dan perubahan cara bereaksi terhadap suatu perangsang tertentu.

Pembelajaran merupakan suatu proses yang fundamental terjadi pada diri seseorang, yang dapat terjadi setiap saat, ketika orang melakukan kegiatan belajar sesungguhnya telah terjadi proses pembelajaran. Kegiatan kursus atau pelatihan dengan tujuan untuk memberikan pengetahuan, keterampilan, dan sikap kepada warga belajar pada dasarya juga terjadi sebuah proses pembelajaran.

Demikian halnya yang terjadi pada pelatihan KWD adalah merupakan proses pembelajaran. Program KWD adalah merupakan salah satu bentuk dari kegiatan satuan pendidikan luar sekolah. KWD merupakan salah satu program pendidikan luar sekolah yaitu PKH untuk membekali warga belajar agar dapat menjalankan tugas hidupnya secara mandiri di masyarakat. Melalui PKH seseorang dapat memperoleh pengetahuan dan keterampilan sikap sebagai modal dasar untuk melakukan kegiatan usaha. Dengan berbekal pengetahuan dan keterampilan, seseorang akan dapat bekerja sesuai dengan potensi dirinya, sehingga dapat memperoleh penghasilan untuk memenuhi kebutuhan dan meningkatkan kualitas hidupnya. Pengetahuan dan keterampilan yang dibutuhkan dapat diperoleh melalui kegiatan pembelajaran dalam kursus atau pelatihan.

Komponen (raw input) yaitu peserta pelatihan yang mempunyai karakteristik internal dan eksternal. Karakterisitik internal meliputi atribut fisik, psikis, dan fungsional. Sedangkan karakteristik eksternal merupakan komponen yang penting dalam kegiatan pembelajaran. Proses pembelajaran yaitu interaksi edukatif antara masukan sarana, terutama pelatih dengan pe- 
serta didik melalui pembelajaran, bimbingan dan penyuluhan dengan menggunakan pendekatan berkelanjutan dan berdaur dari pendekatan remaja ke andragogi. Komponen out put keluaran yang dievaluasi adalah kuantitas dan kualitas. Kemudian kompenen other input adalah sumber daya dukung yang memungkinkan luaran dapat menerapkan hasil belajarnya.

Komponen-komponen tersebut merupakan unsur yang harus ada dalam kegiatan pembelajaran pelatihan PLS, agar proses pembelajaran dalam pelatihan dapat mencapai sasaran yang diinginkan. Dalam kegiatan pembelajaran terdapat interaksi antara siswa atau warga belajar dengan guru atau narasumber. Menurut Sudjana (2005: 8), pembelajaran dapat diberi arti setiap upaya yang sistematik dan disengaja oleh pendidik untuk menciptakan kondisi-kondisi agar peserta didik melakukan kegiatan belajar. Dalam kegiatan belajar berlangsung terdapat interaksi edukatif antara waga belajar dengan pelatih yang melakukan kegiatan membelajarkan. Belajar dapat dipandang sebagai suatu proses dan sebagai hasil. Pendidikan dipandang sebagai suatu proses adalah suatu upaya yang wajar melalui proses penyesuaian tingkah laku untuk mencapai tujuan pembelajaran. Sedangkan belajar dipandang sebagai hasil adalah adanya perubahan tingkah laku sebagai hasil belajar sebagai akibat dari proses belajar. Tujuan pembelajaran adalah terjadi perubahan perilaku warga belajar dari sebelum dan sesudah melakukan kegiatan belajar.

Proses pembelajaran dipengaruhi oleh faktor internal dan eksternal warga belajar. Faktor internal adalah faktor yang berasal dari diri warga belajar itu sendiri yang meliputi komponen minat, motivasi berprestasi, dan partisipasi warga belajar. Sedangkan faktor eksternal adalah faktor yang berasal dari luar diri warga belajar meliputi komponen narasumber teknis, kurikulum pelatihan, sarana dan prasarana pelatihan, serta proses pembelajaran dan lembaga penyelengara.

Baik faktor internal maupun faktor eksternal akan mempengaruhi hasil pembelajaran yang dilakukan, karena faktor-faktor tersebut mempunyai kaitan fungsional terhadap peningkatan kompetensi berwirausaha dalam pembibitan karet unggul bagi warga belajar yang meliputi pengetahuan, keterampilan, dan sikap berwirausaha. Dengan demikian, melalui proses pembelajaran dalam KWD pembibitan karet unggul akan dapat meningkatkan semangat dan jiwa berwirausaha.

\section{METODOLOGI PENELITIAN}

Metode yang digunakan dalam penelitian ini adalah research and development (R\&D) dengan pendekatan kuantitatif, uji coba model pengembangan menggunakan desain eksperimental yaitu nonequivalent control group design. Penelitian ini diawali penelitian korelasional tahapan dalam penelitian dan pengembangan (R\&D) dalam penelitian ini secara operasional mengadopsi model yang dikembangkan oleh Sugiyono (2008: 298) yang terdiri dari (1) potensi dan masalah; (2) mengumpulkan informasi; (3) pengembangan model; (4) validasi model; (5) revisi model; (6) uji coba model; (7) revisi model; (8) uji coba lebih luas; dan (9) revisi model akhir.

Penelitian dilaksanakan di Desa Semuli Jaya Kecamatan Abung Semuli dan Desa Bumi Raharja Kecamatan Abung Surakarta Kabupaten Lampung Utara Provinsi Lampung yang bekerja sama dengan Sanggar Kegiatan Belajar (SKB) Lampung Utara. Lokasi penelitian ini merupakan wilayah desa binaan SKB Lampung Utara. Penelitian korelasi sebagai penelitian pendahuluan dan untuk menguji hipotesis korelasi menggunakan uji korelasi product moment dari Pearson dan regresi linier sederhana sedangkan untuk menguji efektivitas model terhadap peningkatan kompetensi berwirausaha warga belajar, digunakan adalah uji perbedaaan rata-rata, uji statistik parametrik menggunakan uji t ( $\mathrm{t}$ test). Penelitian eksperimen uji coba tahap I dan tahap II dilaksanakan pada tanggal 6 Agustus-15 September 2010.

Adapun model hipotesis penelitian yang diajukan untuk mengetahui efektivitas model yang dikembangkan adalah "model kursus wirausaha desa pembibitan karet unggul untuk meningkatkan kompetensi berwirausaha warga belajar." Sedangkan hipotesis statistik yang dirumuskan sebagai acuan dalam pengujian beda ratarata adalah sebagai berikut.

1. Ho: tidak terdapat perbedaan peningkatan kompetensi berwirausaha warga belajar antara pelatihan yang menggunakan model yang dirancang dan model yang sudah ada.

2. Ha: terdapat perbedaan peningkatan kompetensi berwirausaha warga belajar antara pelatihan yang menggunakan model yang dirancang dan model yang sudah ada. 


\section{HASIL PENELITIAN}

\section{Hasil Penelitian}

Penelitian diawali dengan proses identifikasi kebutuhan, penelitian korelasional analisis SWOT pelaksanaan program pendidikan kecakapan hidup di SKB Lampung Utara. Proses identifikasi kebutuhan, sumber dan kemungkinan munculnya hambatan dalam pelaksanaan program dilakukan oleh peneliti dengan menggunakan beberapa metode, antara lain korelasi menunjukkan terdapat sumbangan variabel-variabel bebas terhadap variabel terikat, variabel minat warga belajar $\left(\mathrm{X}_{1}\right)$ terhadap kompetensi berwirausaha $(\mathrm{Y})$ sebesar $35.2 \%$, variabel motivasi berprestasi $\left(X_{2}\right)$ terhadap $Y$ sebesar $41.22 \%$, variabel partisipasi warga belajar $\left(\mathrm{X}_{3}\right)$ terhadap $Y$ sebesar $35.64 \%$, variabel kompetensi NST $\left(\mathrm{X}_{4}\right)$ terhadap $\mathrm{Y}$ sebesar $35.40 \%$, variabel kurikulum pelatihan $\left(X_{5}\right)$ terhadap $Y$ sebesar $34.34 \%$, variabel sarana dan prasarana $\left(X_{6}\right)$ terhadap $Y$ sebesar $53.87 \%$, variabel proses pembelajaran $\left(X_{7}\right)$ terhadap $Y$ sebesar $31.92 \%$, dan variabel lembaga penyelenggara $\left(X_{8}\right)$ terhadap Y sebesar 26.32.

Berdasarkan hasil perhitungan analisis korelasi secara bersama-sama variabel-variabel bebas terhadap variabel terikat kompetensi berwirausaha $(Y)$ atas minat warga belajar, motivasi berprestasi, partisipasi warga belajar, kompetensi NST, kurikulum pelatihan, sarana dan prasarana, proses pembelajaran, dan lembaga penyelenggara $\left(R_{y}\left[_{x 1}, x_{2}, x_{3}, x_{4}, x_{5}, x_{6}, x_{7}, x_{8}\right]\right)$ diketahui $R$ sebesar 0.898 , koefisien determinasi $\left(R^{2}\right)$ sebesar 0.743 dan nilai $F$ yang ditunjukkan oleh koefisien regresi ganda sebesar 12.563 nilai yang diperoleh signifikan pada taraf signifikansi 0.000 . Hal ini menunjukkan bahwa kompetensi berwirausaha warga belajar sebesar $R^{2} 0.743$ $X 100 \%=74.3 \%$ setelah mengikuti pelatihan dan $25.7 \%$ sisanya dipengaruhi variabel lain.

\section{Pengembangan Model KWD Pembibitan Karet Unggul}

Model KWD pembibitan karet unggul untuk meningkatkan kompetensi berwirausaha warga belajar, merupakan suatu upaya untuk mengatasi permasalahan yang ada dalam masyarakat dengan cara meningkatkan pengetahuan, keterampilan, dan sikap. Kegiatan tersebut merupakan kegiatan pendidikan dan pelatihan yang harus diraskan oleh warga masyarakat. Pendidikan sebagai hak asasi manusia tercantum pada pasal 28 ayat (2) UUD 1945 yang tertulis "Setiap orang berhak mengembangkan diri melalui pemenuhan kebutuhan dasarnya, berhak mendapatkan pendidikan dan memperoleh manfaat dari ilmu pengetahuan dan teknologi, seni budaya, demi meningkatkan kualitas hidupnya, serta demi kesejahteraan umat manusia."

Berangkat dari kesadaran akan pentingnya pendidikan bagi kemajuan bangsa, maka Pemerintah Indonesia melalui Undang-undang RI Nomor 20 tahun 2003 melakukan pembaharuan sistem pendidikan nasional guna menjamin pemerataan kesempatan pendidikan, peningkatan mutu, serta relevansi dan efisiensi manajemen pendidikan untuk menghadapi tantangan sesuai dengan tuntutan perubahan kehidupan lokal, nasional, dan global.

Data dari Sakernas BPS tahun 2007, bahwa jumlah pengangguran terbuka mencapai 10,01 juta orang atau turun sekitar $8,42 \%$ dari 10,93 juta orang pada Agustus 2006 dan turun $5,08 \%$ dari 10,55 orang pada Februari 2007. Dilihat dari latar belakang pendidikannya $31 \%$ berpendidikan SD ke bawah, $25 \%$ berpendidikan SLTP, 36\% berpendidikan SLTA, dan 7\% berpendidikan perguruan tinggi.

Ada tiga faktor yang menyebabkan terjadinya pengangguran. Pertama, jumlah pencari kerja lebih besar daripada jumlah kesempatan kerja yang tersedia. Kedua, kesenjangan antara kualitas pencari kerja dengan kualifikasi yang dibutuhkan oleh pasar kerja, tenaga kerja yang ada tidak memiliki pengetahuan dan keterampilan yang dibutuhkan oleh lapangan kerja. Ketiga, terjadinya pemutusan hubungan kerja (PHK) karena alasan efisiensi dan kebangkrutan dunia usaha dan dunia industri (DUDI) akibat krisis yang berkepanjangan .

Dari ketiga faktor tersebut, faktor pertama dan kedua merupakan faktor dominan yang menyebabkan pengangguran. Terjadinya masalah pengangguran tidak hanya disebabkan oleh kesenjangan antara jumlah pencari kerja dan kesempatan kerja yang tersedia. Banyak kasus, kesempatan kerja tersedia baik di dalam maupun luar negeri, tetapi pencari kerja tidak memiliki kualifikasi yang sesuai dengan kebutuhan calon pengguna tenaga kerja.

Akibatnya, kesempatan kerja tersebut tidak termanfaatkan, dan konsekuensi berikutnya jumlah penganggur pun makin bertambah. Berawal dari kondisi lapangan inilah dipandang perlu adanya KWD pembibitan karet unggul bagi warga masyarakat desa usia 15-35 yang masih menganggur, tidak memilki pengetahuan, keterampilan, dan pekerjaan tetapi mempunyai motivasi berprestasi untuk berwirausahaha mandiri, sehingga dapat memperoleh pekerjaan sesuai dengan kompetensi yang dimilikinya.

Pengembangan model KWD pembibitan karet unggul bagi warga masyarakat desa yang tidak mem- 
punyai pengetahuan, keterampilan, dan masih menganggur merupakan strategi alternatif, terobosan kegiatan inovatif agar menghasilkan lulusan peserta kursus yang siap bekerja secara mandiri dalam bidang pembibitan karet unggul, baik secara individual maupun berkelompok. Dalam model ini terdapat beberapa komponen yang dilibatkan di dalam pelatihan, yaitu aspek instrumental yang dikelompokkan ke dalam faktor internal dan eksternal. Faktor internal pelatihan meliputi minat warga belajar, motivasi berprestasi, dan partisipasi warga belajar. Sedangkan faktor eksternal meliputi kompetensi NST, kurikulum pelatihan, sarana dan prasarana, proses pembelajaran, dan lembaga penyelenggara.

Adapun model yang dikembangkan sebagai berikut.

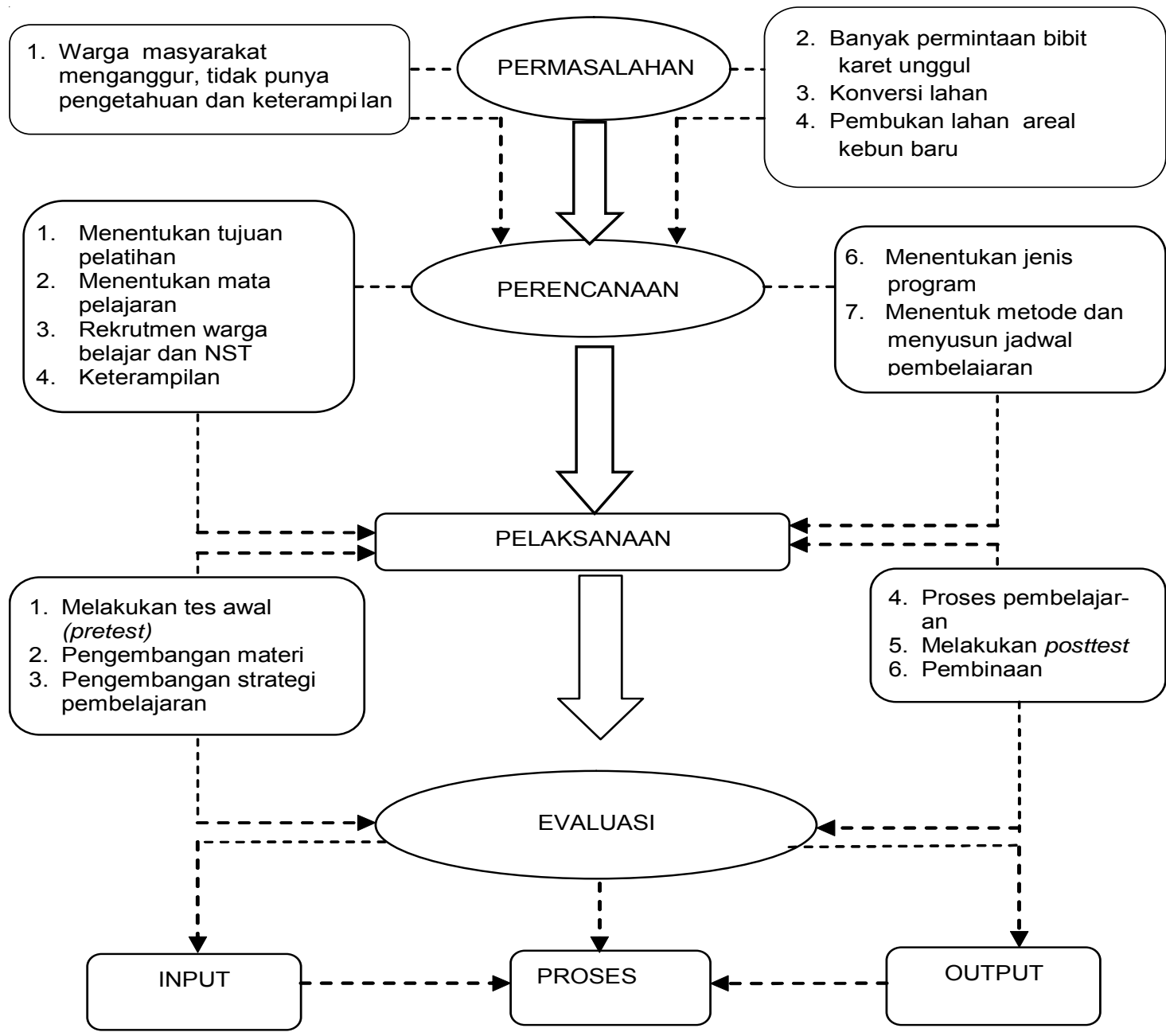

Gambar 2. Model KWD Pembibitan Karet Unggul untuk Meningkatkan Kompetensi Berwirausaha

\section{Uji Efektivitas Model}

Uji efektivitas model dilakukan melalui uji perbedaan rata-rata skor kelompok eksperimen dan kelompok kontrol.

\section{Eksperimen uji coba tahap I}

Hasil uji coba tahap I diperoleh data dari kelompok kontrol dan eksperimen yang dideskripsikan pada tabel 1 sebagai berikut.

Tabel1. Deskripsi Data Penelitian Eksperimental Uji Coba Tahap I

\begin{tabular}{|c|c|c|c|c|c|c|c|c|c|}
\hline Variabel & \multicolumn{4}{|c|}{$\begin{array}{c}\text { Kelompok Kontrol Uji Coba } \\
\text { Tahap I }\end{array}$} & Variabel & \multicolumn{4}{|c|}{$\begin{array}{c}\text { Kelompok Eksperimen Uji Coba } \\
\text { Tahap I }\end{array}$} \\
\hline $\begin{array}{l}\text { Kompetensi } \\
\text { berwirausaha }\end{array}$ & $\mathrm{N}$ & Mean & $\begin{array}{l}\text { S. } \\
\text { baku }\end{array}$ & $\begin{array}{l}\text { Peningkatan } \\
\text { dari pretes ke } \\
\text { posttest }\end{array}$ & $\begin{array}{l}\text { kompetensi } \\
\text { berwirausaha }\end{array}$ & $\mathrm{N}$ & Mean & S.baku & $\begin{array}{l}\text { Peningkatan } \\
\text { dari pretes ke } \\
\text { posttest }\end{array}$ \\
\hline Pretest & 18 & 62.00 & 5.213 & \multirow{2}{*}{$\begin{array}{c}2.44 \\
\text { atau } \\
3.94 \%\end{array}$} & Pretest & 18 & 62.06 & 5.139 & \multirow{2}{*}{$\begin{array}{l}5.88 \\
\text { Atau } \\
9.54\end{array}$} \\
\hline Postest & 18 & 64.44 & 4.755 & & Postest & 18 & 67.94 & 4.976 & \\
\hline
\end{tabular}


Dari tabel di atas, dapat dikatakan bahwa telah terjadi peningkatan skor rata-rata (mean) dari pretest ke posttest. Perbedaan peningkatan skor tersebut berbeda secara signifikan skor rata-rata kompetensi berwirausaha warga belajar. Pada awal sebelum terjadi proses pembelajaran kedua kelompok dilakukan pretest menunjukkan keadaan yang relatif sama. Peningkatan skor rata-rata pada uji coba tahap I pada kelompok kontrol sebesar 2.44 atau 3.94\%. Sedangkan peningkatan skor rata-rata pada kelompok perlakuan atau eksperimen sebesar 5.88 atau $9.54 \%$. Peningkatan tersebut menunjukkan bahwa terdapat peranan perlakuan untuk meningkatkan kompetensi berwirausaha bagi warga belajar pembibitan karet unggul.

Dalam penelitian eksperimental, pada uji coba tahap I dilakukan uji normalitas dengan uji KolmogorovSmirnov pada taraf signifikansi $(\alpha)$ sebesar 0.05 . Hasil perhitungan uji normalitas dengan menggunakan rumus kolmogorov semirnov diperoleh nilai signifikansi sebagai berikut.

Tabel 2. Uji Normalitas Kelompok Eksperimen dan Kelompok Kontrol

\begin{tabular}{|c|c|c|c|c|c|c|c|c|c|c|}
\hline \multicolumn{4}{|c|}{ Levene Statistic } & \multicolumn{2}{|c|}{ df1 } & df2 & \multicolumn{3}{|c|}{ Sig. } & \\
\hline \multicolumn{4}{|c|}{.172} & \multicolumn{2}{|c|}{1} & 34 & \multicolumn{3}{|c|}{.681} & \\
\hline & $\mathrm{F}$ & Sig. & $t$ & df & tailed) & Difference & Difference & Lower & Upper & \\
\hline \begin{tabular}{|c|l} 
THP & Equal \\
I & variances \\
& assumed
\end{tabular} & . 172 & .681 & 2.15 & 34 & . 038 & 3.500 & 1.622 & .203 & 6.797 & ance. \\
\hline \begin{tabular}{|l|}
$\begin{array}{l}\text { Equal } \\
\text { variances not } \\
\text { assumed }\end{array}$ \\
\end{tabular} & & & 2.15 & 33.930 & .038 & 3.500 & 1.622 & .203 & 6.797 & 7 \\
\hline
\end{tabular}

nilai signifikansi $0.200>0.05$ dan kelompok kontrol diperoleh nilai signifikansi $0.200>0.05$, berarti sampel kedua kelompok berasal dari populasi yang berdistribusi normal. Uji homogenitas yang digunakan adalah uji Lavene dengan taraf signifikansi $(\alpha)$ sebesar 0.05 . Dari uji homogenitas diperoleh nilai tes homogenitas pada tabel berikut.

Tabel 3. Uji Homogenitas Varian

Berdasarkan uji F Levene's pada tabel di atas nilai signifikan $0.681>$ nilai signifikansi ( ) 0.05 hal ini berarti nilai bahwa $\mathrm{H}_{0}$ diterima atau sampel berasal dari populasi-populasi yang memiliki varians yang sama (homogen).
Untuk menguji perbedaan rata-rata t-test independent samples test dengan hasil perhitungan pada tabel berikut ini.

Tabel 4.Uji-t Tes Kelompok Eksperimen dan Kontrol Tahap I

Sumber: Direktorat Jenderal Lembaga Pemasyarakatan, Maret 2000.

Berdasarkan tabel di atas, digunakan untuk menguji perbedaan rata-rata tes, yaitu uji-t. Uji-t untuk membuktikan apakah kedua rata-rata skor populasi berbeda atau tidak. Pasangan hipotesis nol dan hipotesis alternatif adalah sebagai berikut.

$\mathrm{H}_{0}$ : tidak terdapat perbedaan peningkatan kompetensi berwirausaha warga belajar antara pelatihan yang menggunakan model yang dirancang dan model yang sudah ada.

$\mathrm{H}_{\mathrm{a}}$ : terdapat perbedaan peningkatan kompetensi berwirausaha warga belajar antara pelatihan yang menggunakan model yang dirancang dan model yang sudah ada.

Uji statistik yang digunakan adalah uji-t dua pihak. Uji-t dua pihak dengan taraf signifikansi $(\alpha) 0.05$ dengan kriteria uji sebagai berikut.

a. Jika $t_{\text {hitung }}$ terletak antara $-t_{\text {tabel }}$ dan $t_{\text {tabel }}$ atau $-t_{1}$ $1 / 2 \alpha<$ thitung $<\mathrm{t}_{\text {hitung }}<-\mathrm{t} 1-1 / 2 a$ á, maka $\mathrm{H}_{0}$ diterima.

b. Jika $t$ mempunyai harga yang lain tidak terletak antara $\mathrm{t}_{\text {hitung }}$ terletak antara $-\mathrm{t}_{\text {tabel }}$ dan $\mathrm{t}_{\text {tabel }}$, maka $\mathrm{H}_{0}$ ditolak.

Berdasarkan tabel 4 di atas, dengan taraf signifikan (á) 0.05 diperoleh $t_{\text {hitung }}$ sebesar 2.157 dengan df $=18+18-2=34$ dengan kriteria uji 2 pihak $t_{0.025}$ sebesar 2.034, berdasarkan kriteria uji tersebut maka $\mathrm{H}_{0}$ tidak diterima karena $\mathrm{t}_{\text {hitung }}$ tidak terletak di antara $-2.034<$ $\mathrm{t}_{\text {hitung }}<2.034$ berarti Ha diterima dan dapat disimpulkan bahwa terdapat perbedaan peningkatan kompetensi berwirausaha warga belajar antara pelatihan yang menggunakan model yang dirancang dan model yang sudah ada.

2. Eksperimen uji coba tahap II

Hasil uji coba tahap I diperoleh data dari kelompok kontrol dan eksperimen yang dideskrisikan pada tabel 5 sebagai berikut. 
Tabel 5. Deskripsi data Data Penelitian Eksperimental Uji Coba Tahap II

\begin{tabular}{|c|c|c|c|c|c|c|c|c|c|}
\hline Variabel & \multicolumn{4}{|c|}{$\begin{array}{c}\text { Kelompok Kontrol Uji Coba } \\
\text { Tahap ॥ }\end{array}$} & Variabel & \multicolumn{4}{|c|}{$\begin{array}{c}\text { Kelompok Eksperimen Uji Coba } \\
\text { Tahap \| }\end{array}$} \\
\hline $\begin{array}{l}\text { kompeten } \\
\text { si } \\
\text { berwiraus } \\
\text { aha }\end{array}$ & $N$ & Mean & S. baku & $\begin{array}{l}\text { Peningka } \\
\text { tan dari } \\
\text { pretes ke } \\
\text { post test }\end{array}$ & $\begin{array}{l}\text { kompeten } \\
\text { si } \\
\text { berwiraus } \\
\text { aha }\end{array}$ & $\mathrm{N}$ & Mean & S.baku & $\begin{array}{l}\text { Peningkat } \\
\text { an dari } \\
\text { pretes ke } \\
\text { post test }\end{array}$ \\
\hline Pretest & 20 & 51.95 & 3.486 & $\begin{array}{l}9.35 \\
\text { atau }\end{array}$ & Pretest & 20 & 51.85 & 3.329 & $\begin{array}{c}18 \\
\text { Atau }\end{array}$ \\
\hline Postest & 20 & 61.30 & 4.964 & $17.99 \%$ & \begin{tabular}{|l} 
Postest \\
\end{tabular} & 20 & 69.85 & 4.603 & $34.71 \%$ \\
\hline
\end{tabular}

Dari tabel di atas, dapat dikatakan bahwa telah terjadi peningkatan skor rata-rata (mean) dari pretest ke posttest. Perbedaan peningkatan skor tersebut berbeda secara signifikan skor rata-rata kompetensi berwirausaha warga belajar. Pada awal sebelum terjadi proses pembelajaran kedua kelompok dilakukan pretest menunjukkan keadaan yang relatif sama. Peningkatan skor rata-rata pada uji coba tahap II pada kelompok kontrol sebesar 9.35 atau $17.95 \%$. Sedangkan peningkatan skor rata-rata pada kelompok perlakuan atau eksperimen sebesar 18 atau $34.71 \%$. Peningkatan tersebut menunjukkan bahwa terdapat peranan perlakuan untuk meningkatkan kompetensi berwirausaha bagi warga belajar pembibitan karet unggul.

Dalam penelitian eksperimental, pada uji coba tahap II dilakukan uji normalitas dengan uji KolmogorovSmirnov pada taraf signifikansi $(\alpha)$ sebesar 0.05 . Hasil perhitungan uji normalitas dengan menggunakan rumus kolmogorov semirnov diperoleh nilai signifikansi sebagai berikut.

Tabel 6. Uji Normalitas Kelompok Eksperimen dan Kontrol

a. Lilliefors Significance Correction

*. This is a lower bound of the true significance.

Data kelompok eksperimen ternyata diperoleh nilai signifikansi $0.200>0.05$ dan kelompok kontrol diperoleh nilai signifikansi $0.074>0.05$, berarti sampel kedua kelompok berasal dari populasi yang berdistribusi normal. Uji homogenitas yang digunakan adalah uji Lavene dengan taraf signifikansi $(\alpha)$ sebesar 0.05 . Dari uji homogenitas diperoleh nilai tes homogenitas pada tabel berikut.

Tabel 7. Uji Homogenitas Varian

Berdasarkan uji $\mathrm{F}$ Levene's pada tabel di atas nilai signifikan $0.681>$ nilai signifikansi $(\alpha) 0.05$ hal ini berarti nilai bahwa $\mathrm{H}_{0}$ diterima atau sampel berasal dari populasi-populasi yang memiiki varians yang sama (homogen).

Untuk menguji perbedaan rata-rata t-test independent samples test dengan hasil perhitungan pada tebel berikut ini.

Tabel 8. Uji-t Tes Kelompok Eksperimen dan Kontrol Tahap II

Berdasarkan tabel di atas, digunakan untuk menguji perbedaan rata-rata tes, yaitu uji-t. Uji-t untuk membuktikan apakah kedua rata-rata skor populasi berbeda atau tidak. Pasangan hipotesis nol dan alternatif adalah sebagai berikut.

$\mathrm{H}_{0}$ : tidak terdapat perbedaan peningkatan kompetensi berwirausaha warga belajar antara pelatihan yang menggunakan model yang dirancang dan model yang sudah ada.

$\mathrm{H}_{\mathrm{a}}$ :terdapat perbedaan peningkatan kompetensi berwirausaha warga belajar antara pelatihan yang menggunakan model yang dirancang dan model yang sudah ada.

Uji statistik yang digunakan adalah uji-t dua pihak. Uji-t dua pihak dengan taraf signifikansi $(\alpha) 0.05$ dengan kriteria uji sebagai berikut.

a. Jika $\mathrm{t}_{\text {hitung }}$ terletak antara $-\mathrm{t}_{\text {tabel }}$ dan $\mathrm{t}_{\text {tabel }}$ atau $-\mathrm{t}_{1}$ $1 / 2 \alpha<$ thitung $<\mathrm{t}_{\text {hitung }}<-\mathrm{t} 1-1 / 2 a$ á, maka $\mathrm{H} 0$ diterima.

b. Jika $t$ mempunyai harga yang lain tidak terletak antara $t_{\text {hitung }}$ terletak antara $-t_{\text {tabel }}$ dan $t_{\text {tabel }}$, maka $\mathrm{HO}$ ditolak.

Berdasarkan tabel 8 di atas, dengan taraf signifikan ( ) 0.05 diperoleh $t_{\text {hitung }}$ sebesar 5.648 dengan 
$\mathrm{df}=20+20-2=38$ dengan kriteria uji 2 pihak $\mathrm{t}_{0.025}$ sebesar 2.038, berdasarkan kriteria uji tersebut maka $\mathrm{H}_{0}$ tidak diterima karena $t_{\text {hitung }}$ tidak terletak di antara $-2.038<\mathrm{t}$ hitung $<2.038$ berarti Ha diterima dan dapat disimpulkan bahwa terdapat perbedaan peningkatan kompetensi berwirausahaha warga belajar antara pelatihan yang menggunakan model yang dirancang dan model yang sudah ada berarti model tersebut efektif.

\section{KESIMPULAN}

\section{Kesimpulan}

Hasil penelitian juga menunjukkan model KWD pembibitan karet unggul telah tepat digunakan untuk meningkatkan kompetensi berwirausaha warga belajar dan secara empiris telah terbukti model tersebut telah dapat meningkatkan kompetensi berwirausaha warga belajar.

Model KWD pembibitan karet unggul yang dikembangkan untuk meningkatkan kompetensi berwirausaha secara empiris mampu meningkatkan skor kompetensi berwirausaha warga belajar pembibitan karet unggul. Dibuktikan dengan uji beda rata-rata skor posttest kompetensi berwirausaha pada uji coba tahap I diperoleh $t_{\text {hitung }}$ sebesar 2.157 tidak terletak di antara $t_{0.025}-2.034$ $<\mathrm{t}_{\text {hitung }}<2.034$ berarti Ha diterima dan pada uji coba tahap II diperoleh $t_{\text {hitung }}$ sebesar 5.648 tidak terletak di antara $\mathrm{t}_{0.025}-2.038<\mathrm{t}_{\text {hitung }}<2.038$ berarti Ha diterima. Saran

Pertama, bagi pengambil kebijakan. Berkaitan dengan keberhasilan penerapan model KWD pembibitan karet unggul terbukti efektif dapat meningkatkan kompetensi berwirausaha warga belajar. Tentunya diperlukan apresiasi positif oleh penentu kebijakan untuk memfasilitasi kegiatan pelatihan sejenis sehingga dapat menghasilkan tenaga-tenaga terampil di bidang perkebunan. Di samping itu, perlu dilakukan pembinaan bagi para penangkar baik secara individu maupun berkelompok dengan pelayanan prima agar dapat meneruskan keberlangsungan usaha pembibitan karet unggul menjamin ketersediaan dan mudah dalam pe- masaran.

Kedua, bagi praktisi. Kebutuhan akan bibit karet unggul tidak dapat disangkal lagi terutama di daerah perkebunan, kebutuhan tersebut berusaha dipenuhi oleh para penangkar bibit karet unggul yang di bawah binaan dinas perkebunan dan kehutanan dengan bekerja sama berbagai pihak yang berkepentingan. Rekomendasi ditujukan pada praktisi lapangan dalam pembibitan karet unggul agar penangkar muda dijadikan mitra dalam hal penangkaran baik secara individu maupun berkelompok, untuk menjamin dan menjaga kualitas bibit yang dihasilkan. Selain untuk menjaga kualitas bibit, juga dalam pemasaran agar mampu menstabilkan harga dan menghindari praktik pemasaran yang merugikan berbagai pihak.

Ketiga, bagi penelitian lanjutan. Rekomendasi ditujukan kepada peneliti lanjutan terutama dalam pengembangan program pendidikan luar sekolah yang bersumber dari penelitian ini adalah pertama, model yang dikembangkan telah melalui pengujian atau validasi baik secara teoretis maupun empiris, sehingga layak untuk disebut sebagai model. Meski telah mengalami pengujian secara empiris, namun uji coba yang dilakukan masih terbatas dan perlu melibatkan sasaran yang lebih luas dan diadakan penelitian lanjutan. Kedua, model yang dikembangkan di bidang perkebunan masih terbatas pada pembibitan karet unggul untuk peningkatan kompetensi berwirausaha warga belajar disarankan perlu adanya penelitian.

\section{DAFTAR PUSTAKA}

Depdagri. (2007). Modul manajemen dan pengembangan sumber daya manusia. Jakarta: Lembaga Administrasi Negara.

Depdiknas Ditjen PLS BPPLSP II. (2007). Faktor-faktor determinan penyelenggaraan PKBM berbasis keunggulan komparatif Lokal. Jawa Barat.

Depdiknas Ditjen PNFI Direktorat Pembinaan Kursus dan Kelembagaan. (2008). Pedoman program kursus wirausaha pedesaan (KWD). Jakarta.

If, J \&Tesoriero F. (2008). Alternatif pengembangan masyarakat di era globalisasi community development. Yogyakarta: Pustaka Pelajar.

Kamil, M. (2010). Model pendidikan dan pelatihan (konsep dan aplikasi). Bandung: Alfabeta.

Sakernas BPS tahun. (2007). Jakarta: BPS.

Safaruddin. (2008). Efektivitas kebijakan pendidikan konsep, strategi, dan aplikasi kebijakan menuju organisasi sekolah efektif. Jakarta: Rineka Cipta.

Sudjana, H.D. (2000). Manajemen program pendidikan untuk pendidikan luar sekolah dan pengembangan sumber daya manusia. Bandung: Falah Production. 
Sudjana. (2005). Metode dan teknik pembelajaran partisipatif. Bandung: Falah Production.

Sugiyono. (2008). Metode penelitian kuantitatif, kualitatif dan $R \& D$. Cetakan ke-5. Bandung: CV. Alfabeta.

Suryadi, A.(2009). Mewujudkan masyarakat pembelajar, konsep, kebijakan, dan implementasi. Bandung: Widya Aksara Press.

Suryadi, A. (2010). Kependudukan dan pembangunan pendidikan. Diakses pada tanggal 10 Agustus dari http://www.depdiknas.go.id/publikasi/ balitbang/070/j70_01. pdf. 